\title{
Book review: The Innocent and the Criminal Justice System: A Sociological Analysis of Miscarriages of Justice
}

DOI:

$10.1177 / 1748895814553072$

Link to publication record in Manchester Research Explorer

\section{Citation for published version (APA):}

Speechley, N-E. (2015). Book review: The Innocent and the Criminal Justice System: A Sociological Analysis of Miscarriages of Justice. Criminology and Criminal Justice, 15(1), 124-127.

https://doi.org/10.1177/1748895814553072

\section{Published in:}

Criminology and Criminal Justice

\section{Citing this paper}

Please note that where the full-text provided on Manchester Research Explorer is the Author Accepted Manuscript or Proof version this may differ from the final Published version. If citing, it is advised that you check and use the publisher's definitive version.

\section{General rights}

Copyright and moral rights for the publications made accessible in the Research Explorer are retained by the authors and/or other copyright owners and it is a condition of accessing publications that users recognise and abide by the legal requirements associated with these rights.

\section{Takedown policy}

If you believe that this document breaches copyright please refer to the University of Manchester's Takedown Procedures [http://man.ac.uk/04Y6Bo] or contact uml.scholarlycommunications@manchester.ac.uk providing relevant details, so we can investigate your claim.

\section{OPEN ACCESS}


negatively impact on the local position of police, both in a social and governmental context. The author is furthermore critical about arguments regarding the reduction of bureaucratic and administrative hurdles and the enhancement of police craftsmanship and doubts that a sufficient system of checks and balances is in place for the current reform. It has, however, been argued by other prominent scholars in the Netherlands that the reform is necessary to overcome inefficiencies created by the many layers of bureaucracy that hampered policing and, in particular, cooperation between police from different districts before the reform.

In Chapter 9, Bo Wennström analyses the recent Swedish police reform to emphasize that centralization, while perhaps appearing a straightforward process, is often very complicated and involves numerous factors. Similar to Belgium, this chapter also highlights several 'scandals' that made reform in Sweden imperative. Major problems that were determined after these events were structural and deriving from a lack of consensus, poor leadership and deficient training. The author concludes with regard to police reforms more generally that they are first initiated, then fail and consequently a new reform is introduced. As a remedy for this 'vicious circle' he proposes that reforms have to address all problems holistically. The entire institution of the 'police' has to be considered, otherwise reforms will always be flawed. Pieter Tops and Ruben Spelier echo this conclusion in Chapter 10. They argue that reforms will not be successful unless they take into account the basic features of the police as a frontline organization and the organization's capacity for learning. Moreover, Tops and Spelier emphasize that new forms of criminality pose challenges which cannot be met by police alone, but have to involve other actors from public and private organizations

These are important conclusions to the book. They reflect several comments made in the introduction with regard to the changing environment of the police and the necessity to become an increasingly accessible body that cooperates with other organizations and the public. The fact that the police is a frontline organization and has a distinct culture is often overlooked. In particular 'top-down' reforms tend to disregard specific practitioner needs and are therefore rejected.

While this appears to be a rather grim conclusion, there are many examples in the recent history of policing in Europe, where police, after initial resistance, have accepted new approaches. The imposition on British police to tape all police interviews under the Police and Criminal Evidence Act 1984 was first vehemently rejected. However, police realized the benefits of this procedure within several years. It can therefore only be hoped that some of the reforms described in this volume will eventually be embraced by both practitioners and citizens and that this happens before a new reform is introduced.

Michael Naughton, The Innocent and the Criminal Justice System: A Sociological Analysis of Miscarriages of Justice, Palgrave Macmillan: London, 2013; 280 pp.: $9780230216907, £ 65.00$ (hbk); $9780230216914, £ 23.99$ (pbk)

Reviewed by: Naomi-Ellen Speechley, University of Oxford, UK

The Innocent and the Criminal Justice System offers insight into different perceptions of what constitutes a miscarriage of justice, how and why wrongful convictions occur and 
the extensive problems that they create. A large body of literature already exists which analyses various definitions of a 'miscarriage of justice', the causes of wrongful conviction and the problems that factually innocent applicants face in getting convictions overturned. However, Naughton's book seeks distinction by using sociological discourse to deconstruct academic notions of 'innocence' and 'miscarriages of justice', which informs his discussion of how safeguards fail the innocent. He undertakes a diagnostic analysis of failings in the justice system which, at times, results in the topic being viewed through the lens of his personal experiences. Whether beneficial or not, this makes his analysis refreshingly distinct from dry, legalistic accounts.

The author draws upon his wealth of experience working with alleged victims of wrongful conviction to address the fallibilities of the criminal justice system from their perspective. This approach focuses attention on the practical realities of being wrongfully convicted. In this respect, it offers an important contribution to the existing literature. The analysis itself fails to contribute substantive new angles to existing debates, however, as the concepts discussed and arguments raised are drawn from Naughton's previous publications. ${ }^{1}$ Nor does the sociological and semantic-heavy perspective provide a recipe for fashioning alternative definitions.

It is commendable that Naughton champions the factually innocent throughout his work, but asking how and why (as opposed to whether and how often) innocent victims of wrongful conviction have been failed by the justice system betrays predisposition. There is little even-handed discussion of the importance of 'due process' in the criminal justice - and specifically appeals - system. This may be because cases involving wrongful conviction resulting from undue process do not produce the same outcry as wrongful convictions of factually innocent applicants.

Any publication claiming to focus on 'the innocent' will incur problems when its arguments or concepts are applied to real life, given that innocence itself is a social construct, spanning varying degrees of culpability. Therefore, while the book shines an important spotlight on widespread problematic practices (such as police breaches of PACE, and prosecution non-disclosure and parole deals) which may cause innocent people to become trapped in the criminal justice system, the persuasive critique should be weighed against the fact that true innocence is difficult to determine. For example, the book contends that wrongful convictions fail to be rectified because criminal justice agencies predominantly look at whether a conviction is safe, rather than investigating leads that could reveal an applicant's innocence. The extent to which this may be true is not quantified - there is little supporting first hand evidence that this contributes to the prolonged wrongful conviction of the factually innocent. Moreover, the author's critique of the criminal justice system is informed by his work with those contesting their convictions, many of whom have not actually been proven innocent. Thus some case or applicant-based arguments risk being at best unsubstantiated or, at worst, based on mistruths.

The book is divided into three main parts. Part I is concerned with the nature and causes of 'miscarriages of justice'. Chapters 1 and 2 unpack three schools of thought surrounding this broad and contested phrase. Although 'miscarriages of justice' and the more specific 'wrongful conviction of the factually innocent' are used interchangeably, Naughton explains that 'miscarriages of justice' can be construed to include the wrongful convictions of guilty applicants where there has been a breach of due process or procedural error, or even a failure by the state to bring the true perpetrators of a crime to 
justice. Against this backdrop, the concept of an 'abortion of justice' is introduced to distinguish 'miscarriages of justice' from cases where wrongful conviction was deliberately caused. This controversial terminology reflects the author's propensity to use dramatic language to highlight the severity of the issue. However, until proof of innocence is found through extensive post-conviction criminal appeals, the typologies carefully identified in the first two chapters have little bearing in practice.

Chapters 3 and 4 provide a full and systematic outline of the predominant causes of both 'miscarriages of justice' and 'abortions of justice'. The constrained relationships between agents involved in the investigation, charge and trial processes, and the key factors that can lead to miscarriages or abortions of justice in individual cases (e.g. professional misconduct) are clearly explained. Naughton also takes care to include broader contributory factors to wrongful conviction, for example elements of the charge and conviction process in general.

Part II addresses the limitations upon the criminal justice system when dealing with claims of innocence. Therein, Chapters 5 and 6 detail how parole operations and appeal court restrictions create extensive barriers for those trying to get wrongful convictions recognized and overturned. Legal technicalities are explained in an accessible manner and with reference to the previously defined categories of 'miscarriages' and 'abortions'. The use of socio-logical analysis here offers insight into natural presumptions of guilt, drawing readers' attention to the reasons behind mistaken and deliberate professional misconduct leading to wrongful convictions. However, Naughton's call for a more objective police and prosecution service in line with the presumption of innocence would likely be hindered by the human fallibilities so carefully discussed and dissected.

Chapter 7 discusses the origins of the Criminal Cases Review Commission and its counterpart organizations overseas, but does not satisfactorily engage with the crucial debate that it 'is not concerned with whether applicants are factually innocent or guilty' (p. 179). Naughton makes this contention, reasoning that the Commission does not live up to what was envisaged when it was created in the wake of several prolific miscarriages of justice (namely the Birmingham Six, Guildford Four and Maguire Seven). Although the underlying reasoning is well evidenced, the assessment that the Commission fails to assist factually innocent applicants due to its overarching concern with correcting apparent breaches of process (p. 162), avoids conceding that the Commission's assessment of whether a conviction is unsafe is a pretty sensible way of tackling wrongful convictions, given that innocence is often unknown. After all, the least safe convictions are those of the innocent.

Part III considers the harmful consequences of wrongful convictions and the limits of redress. Case examples of difficulties experienced by wrongfully convicted applicants bring a personal, human note to the analysis, reminding readers that wrongful convictions create a second victim, to whom the experience is severely damaging - it is not simply a subject of academic deliberation and debate. The inclusion of a chapter alerting readers to the current inadequacies of compensation available for wrongful conviction is particularly important, given the provisions in s. 175 Anti-social Behaviour, Crime and Policing Act 2014 which restrict compensation so that only applicants who can prove their innocence 'beyond reasonable doubt' are eligible. 
Overall, the publication provides a detailed review and comprehensive reflection upon the many factors that precipitate a wrongful conviction, alongside personal case examples. Use of the distinguished concepts of 'innocence' and 'miscarriages of justice' pushes readers' awareness, and he goes some way towards providing recommendations and suggestions for reform. The book calls into account the legitimate and - more worryingly - illegitimate yet common practices contributing to injustice, and produces strong arguments for a more inquisitorial system.

\section{Note}

1. For example, the distinction between a deliberate 'abortion' and an unintentional 'miscarriage' of justice is discussed under different titles in Naughton's earlier edited collection (2010). The original distinction is drawn from Walker and Starmer (1993) and Teubner et al. (2000).

\section{References}

Naughton M (ed.) (2010) The Criminal Cases Review Commission: Hope for the Innocent? Basingstoke: Palgrave Macmillan.

Teubner G, Nobles R and Schiff D (2000) Understanding Miscarriages of Justice: Law, the Media, and the Inevitability of Crisis. Oxford: OUP.

Walker C and Starmer K (eds) (1993) Justice in Error. London: Blackstone. 